\title{
Needs Analysis To Design A Set Of English Teaching Materials For Non-English Subject Teachers
}

\author{
Sri Lestari \\ Universitas Esa Unggul, Jakarta, Indonesia
}

\begin{abstract}
This article aims at describing the rationale and principles of designing English teaching materials for teachers of non-English subjects. Those teachers use English as a medium of instruction. English is used to teach the subjects. To improve the teachers' English skills, the school provided an English course. However, the teaching materials for those specific learners were not available. Therefore, designing materials is needed to precisely fulfil their needs of English in the target professional workplace. A needs analysis was conducted to gather information using questionnaires distributed to the non-English subject teachers as the learners. The data from the questionnaire were analysed qualitatively by interpreting and categorising in themes. Using the needs analysis result, a syllabus was then designed as the guidelines for developing the materials. This paper reports how the needs analysis process is employed to design a set of English teaching materials for nonEnglish subject teachers. The discussion highlighted the present situation, the target situation, the principles of designing English materials. The overview of the designed materials for teachers of non-English subjects was then presented.
\end{abstract}

Keywords: ESP; needs analysis, material development; non-English subject teachers;

\section{Introduction}

The use of English as a medium of instruction at schools has increased including Indonesia. Although international standard schools were abolished, some schools in Indonesia keep using English as a medium of instruction. In primary schools where English is optional, the schools still offer English subjects for parental demand (Kirkpatrick, 2011) and the rapid growth of technology and globalisation. Therefore, teachers in those schools use English as a medium of instruction, 'the use of English language to teach academic subjects in countries where the first language of the majority of the population is not English' (Dearden, 2014:4). One of the schools is Cendekia, an educational foundation comprises a primary school, secondary schools and a college in West Java, Indonesia. Cendekia is preparing to be a bilingual school where teachers use Bahasa Indonesia and English to teach 
the courses. The teachers are expected to be able to use English to teach subjects. Therefore, the school provides an English course for the subject teachers.

This paper aims at describing the rationale and principles of developing English teaching materials, which are intended for teachers of non-English subjects. It is designed to fulfill the need of English teaching materials in Cendekia School. Cendekia requested a professional English course institution to conduct the course. As part of the team in the institution, I am responsible to prepare the materials. Since there is no suitable book available for those teachers from various levels of proficiency, developing materials for those specific learners is needed. The discussion in this paper covers three parts: the teaching context; the details of guiding rationale and principles underpinning the materials and how teaching materials reflect those beliefs.

\section{Literature Review}

The course might be included in English for Specific Purposes (ESP) course since it focused on the specified needs of learners (Dudley-Evans and St John, 1998) and as an approach to language learning that is based on learners needs (Hutchinson and Waters, 1987). ESP branches have English for Academic Purposes (EAP) and English for Occupational (EOP), each of which has many branches. In this case, English is used in the learners' workplaces. English is practiced for working in the school target situation. Therefore, the teaching materials should fulfil the subject teachers' needs for learning English.

Being included in the ESP materials category, the designed materials and the ESP teachers carefully follow the ESP frameworks: the needs analysis, process-led materials, learning-centred rather than language focus, specific learners, authentic and involving adults 
learners. Sifakis in Widodo and Pusporini (2010) addressed the characteristics of teaching ESP:

1. Knowledge skills. Learners need to acquire content knowledge

2. Competence in English for general Purposes which includes four English skills and English sub skills

3. Vocational competence. It is related to professional tasks

4. Specified subject. Learners ability to combine vocational competence and English general competence to handle subject-specified information

5. Need-driven nature of learning. Learn ESP to properly function in workplaces or academic setting where the instruction is English

6. Cultural characteristics. Learners' sense of cultural identity and motivation in ESP

7. Beliefs about language learning

There is no one-size-fits-all approach in a language course. It should be relevant to the needs of specific groups of learners (Long, 2005). One of the ways is basing the course on the survey of learners' needs. Therefore, the needs analysis is imperative to understand the context as the first step of ESP development (Flowerdew, 2013). The term 'needs' might refer to wants, demands, expectations, necessities, lacks and constraints. The goals of doing needs analysis are to aim at specialised instruction for specific purposes or needs; to identify the present situation and target situation; and to bridge the gap between the insiders' perspective and the outsiders' assumption (Widodo and Pusporini, 2010). The process of needs analysis involves the target situation analysis, discourse analysis, present situation analysis and learner factor analysis, and teaching context analysis (Basturkmen, 2010). The process should involve the subject teachers as the learner. 
There are many ways to conduct a needs analysis. According to Hutchinson and Waters (1987), the suggested ways of gathering information on target needs are questionnaires, interviews, observation, etc. Referring to the framework they suggested and Dudley-Evans (2001) the needs analysis questions covered:

- Who are the learners?

- Why are the learners taking the course?

- What is their learning background?

- Where and when will the course take place?

- What do learners think they want to achieve?

- What do students need to do with English?

- Which of the skills do they need to master and how well?

- Which genres do they need to learn, either for comprehension or production purposes?

It seems that needs analysis is a crucial part of the entire process of designing teaching materials for specific purposes. In this paper, the needs analysis is to obtain information from the non-English subject teachers related to their needs of using English as a medium of instruction.

\section{Method}

A qualitative method was employed to obtain insights from the learner-to-be regarding their professional competence as subject teachers at school. A needs analysis was carried out to obtain the data. It is to identify the present situation: the needs of learning English, wants, knowledge and attitude, and the target situation: what learners required to do with a foreign language in the target situation (Dudley-Evans, 2001). Accordingly, the 
teaching materials for teachers in Cendekia considered the results of the needs analysis of two ways: information brief from the school leader and a questionnaire. The brief from the school director was as follows:

1. The course is to give teachers practical English training focusing on the language used in daily education situation and classroom instruction

2. Participants are a mixed group of 25-30 teachers delivering different school subjects

3. The course will be conducted twice a week for three months at school after school hours around 3.30 pm lasts for 90 minutes per session

4. Fun language training is needed to help those teachers also refresh their mind after the tiring teaching days

5. More practical activities to encourage teachers as learners to actively use the language and avoid boring sessions

Questionnaires were distributed to 30 Cendekia subject teachers via Google form. The participants were teachers who registered to attend the English course batch 1 . They were teachers from junior and senior high schools who teach various subjects. They were asked to access and fill in the online form. Their names were kept confidential.

The questionnaire consisted of questions related to personal information, reason and challenges of learning English, their objectives, learning background, language proficiency and their interest. It emphasised on the present situation analysis. It 'draws attention to the gap between what students are able to do with the language at the beginning of the course and what they need to do at the end of the course' (Paltridge and Starfield, 2013:327). 
The data obtained from the needs analysis was organised and interpreted based on the theme: personal information and a summary of what they expect and what they need. The data from the questionnaire were combined with a brief from the school director. Those data were interpreted and categories into themes. The results were used to design the syllabus. The syllabus becomes the guideline for developing the teaching materials.

\section{Results And Discussions}

\section{Using needs analysis to design a syllabus}

All teachers responded to the questionnaire. From 30 responses, the profiles of the target learners are presented in Table 1 below:

\begin{tabular}{|l|l|l|}
\hline Age & 21-30 years old = 12 persons & Adults \\
& 31-40 years-old = 15 persons & Female: 17 \\
& 40 years old and above = 3 persons & Male: 13 \\
\hline Years of experience & $<1$ year = 1 person & \\
& $1-5$ years= 11 persons & \\
& $6-10$ years = 5 persons & \\
& $11-15$ years = 9 persons & \\
& $>15$ years = 4 & \\
\hline School level & Elementary school = 12 persons & \\
& Junior high school = 8 persons & \\
& Senior high school = 12 persons & \\
\hline Subjects & Maths; Sociology, Science; Information \& Technology; & $\begin{array}{l}\text { Note: Elementary school teachers are } \\
\text { responsible for teaching all integrated } \\
\text { subjects }\end{array}$ \\
\hline
\end{tabular}

Table 1.Profile of target learners

The needs analysis of Cendekia teachers is to identify, describe and to examine specific language use and communication in schools and classrooms as their workplace or other activities related to their profession. The summary is presented in Table 2: 


\begin{tabular}{|c|c|}
\hline Reasons and Constraints & $\begin{array}{l}\text { - They have no partners to practice English; lack of practice } \\
\text { - No opportunity to use English they have learnt } \\
\text { - Lack of vocabulary } \\
\text { - Do not know how to use grammar } \\
\text { - Low motivation and confidence } \\
\text { - English is used everywhere, especially online media }\end{array}$ \\
\hline Objectives & $\begin{array}{l}\text { - To be able to understand all simple written and spoken English } \\
\text { - To read foreign newspaper, magazines, articles, etc } \\
\text { - To use English classroom instruction in teaching } \\
\text { - To communicate with native speakers (when going abroad for exchange program) } \\
\text { - To write e-mail and update on social media } \\
\text { - To attend international seminar and workshop } \\
\text { - To welcome foreign guests from partner schools from abroad } \\
\text { - To make teaching preparation (powerpoint presentation) }\end{array}$ \\
\hline Learning background & $\begin{array}{l}\text { Most students had ever taken English course ( }<1 \text { week }=8 \text { persons; } 1-4 \text { weeks }=8 \text { persons; } 1-3 \\
\text { months }=7 \text { person, and more than } 3 \text { months }=12 \text { people) }\end{array}$ \\
\hline $\begin{array}{l}\text { Level of language } \\
\text { proficiency }\end{array}$ & Beginners $=17$ persons; Intermediate $=13$ persons \\
\hline Intended skills & Speaking = 24 persons; Reading = 7 persons; Listening = 1 person; Writing = 1 person \\
\hline Topics/Themes & $\begin{array}{l}\text { All vocabulary; grammar; daily activities at school; technology, environment, sport; music; } \\
\text { culture; news; article; all about conversation; classroom instruction }\end{array}$ \\
\hline
\end{tabular}

Table 2. Analysis of needs survey: target situation and learning needs

The outcome of the analysis is to create target situation-based goals, syllabus, materials and instruction. The syllabus refers to 'a plan of what to be achieved in teaching and learning which consists of four elements: aims, contents, methodology and evaluation' (Breen, 2001: 151). Nunan defines the syllabus as 'being concerned essentially with the selection and grading of content, while methodology is concerned with the selection of learning tasks and activities' (Nunan, 1988a: 5). In other words, the syllabus focuses on what to teach, while methodology emphasis how to teach.

According to the needs analysis results in which learners need to promote communication and interaction, the syllabus will focus on the process. It is more than just learning content but through activities (Prabhu, 1984). This type of syllabus is considered appropriate for the ESP course since it involves teachers and learners' negotiation of the purpose and contents (Breen, 2001). The organisation of the syllabus is also collaboratively decided by both teachers and learners through the needs survey. Moreover, all decisions of content and methods are based on a detailed analysis of learners' reasons for learning and the 
language features in the target situation, which indicate ESP as an approach, not a product (Hutchinson and Waters, 1987).

The organisation of syllabus includes the aims, the language focus (grammar and vocabulary), and four integrated skills. As expected by the target learners, building vocabulary and promoting speaking skills through conversation dominate the teaching materials. Those activities are encapsulated in communicative tasks. Nunan (1991) identifies the characteristics of the communicative approach to language teaching include interaction in the target language, authentic texts; process-oriented language learning; link the classroom language to the outside, and enhancement of learners' experience.

\section{The principles of writing the materials}

Having discussed the needs analysis as the fundamental aspect of ESP and its syllabus, this section examines the principles of materials design. The principles underlie the materials writing as well as inform instructional methods in the classroom (Widodo \& Pusporini, 2010). In this designed materials, I believe that the teaching materials should be interactive and communicative, authentic, and contextual as the basic principles of creating the materials.

\section{1) Interactive and Communicative}

The principle of the materials is encouraging interaction. Interaction not only involves expressions of one's idea but also comprehension of those others by using language focuses on conveying and receiving messages (Rivers, 1987). Long in Wang \& Castro (2010) posits that interaction as a "negotiation of meaning. Classroom interactional tasks to stimulate negotiation of meaning include group work, teachers talk, role-play, etc. (ibid. 2010). 
Materials should contain communicative tasks and stimulate learners' interaction. As stimuli, materials should be interesting, motivating and give learners the opportunity to initiate interaction involving in both the content and language topic, which is required to solve communication problems (Hutchinson \& Waters, 1983). EFL learners who learn to communicate fluently in other languages will spend their time learning the language used in real communicative purposes (Hall, 1995).

Teaching materials ideally provide situations where learners interact with each other in a manner that reflects the situation outside the classroom. Therefore, materials should acknowledge communication challenges. Nunan (1988) suggests information gap activities ensure interaction happens. Furthermore, Morrow in Larsen-Freeman (2000) suggests three features of communicative activities: information gap, choice, and feedback.

It seems that ESP is the best example of communicative teaching. It gears the learners' need. To be truly communicative, Hutchinson and Waters (1983) proposed that ESP materials should be based on 'a real analysis of students need and expectations, learning situation and negotiation with learners' (1983:112).

\section{2) Authentic}

Using authentic texts is the second principle of the proposed designed materials. The advantage of using authentic texts in a language classroom is that learners get exposure to real language being used in a real context (Berardo, 2006) and one way of maintaining motivation (Guariento and Morley, 2001). Authentic texts build a bridging between the classroom languages to real-life language use. 
Nunan (1998b) defines authentic texts are usually produced for another purpose than for teaching language. Therefore, authentic texts might be difficult especially for low proficiency level learners. For them, tasks should be carefully selected, adapted, or simplified (Guariento and Morley, 2001). In the proposed designed materials, searching for some spoken and written texts on the websites is the initial step. Next, select the simple and relevant, authentic texts. The last, making some modifications as needed.

It is challenging to select authentic materials. Regarding ESP materials within a framework of a needs analysis, tasks will be authentic if it relates to the real world needs (Long and Crookes, 1992). In this case, it should be related to school, teacher and educational matters. Guariento and Morley (2001) posit that authenticity lies not only in the genuineness of text but has much to do with the notion of tasks. Tasks can also be contrasted to pedagogic tasks focusing on accuracy rather than language use (McGrath, 2016). Therefore, the material developer should ensure that the tasks for teaching focus on the use of language in the real world. Tasks are to encourage students to produce language. Swain (1985) argues that pedagogic tasks offer opportunities for productions.

\section{3). Contextualised}

Materials should be contextualised to realities, learners' experience, their first language and learners' background of knowledge, and socio-cultural condition. Contextualisation is one of the benefits of teachers-produced materials (Block, 1991) in which it enables teachers as materials developers to overcome some lack of the fit available course book(s) (Howard and Major, 2004). In the proposed materials, the context is the school in Indonesia. Therefore, the topics are organised from classroom activities, education systems, teachers' identity and life, and culture in Indonesia. 
Materials should also contextualise to the syllabus, which includes the intended objectives and meaningful topics for the target language. Topics should relevant to the learners. They should be chosen appropriately to motivate learners and to ensure personal engagement with the materials (ibid. 2004). The topics comprise the materials are about professional teachers, teachers at the school, or teachers in classrooms. Those themes are also linked to the use of information and technology as their daily language exposures.

\section{Overview of the Designed Materials}

How do the designed materials reflect the aforementioned principles? This final section will analyse the principles underlying the materials including the themes or topics, input text, content, activities, visual art and layout.

The main theme of this designed material is a teacher in the 21 st century which is divided into three sub-themes: professional teacher, teachers at school and teachers in a classroom. Those themes or topics refer to the learners' choices in the needs analysis. The topics are presented in units. Each unit has learning objectives describe what students are able to do at the end of the course. Teaching materials should have clear objectives indicating what competencies to achieve (Widodo and Pusporini, 2010). The objectives are presented at the beginning of each unit.

The materials developer attempts to use authentic text. It might be the controversy of using authentic text for the low-level learners, but in this ESP material, simple and authentic texts for both spoken and written are used. The difficulty of the spoken text is related to the familiarity of the learners with the accent and articulation (McGrath, 2016). In addition, most of the authentic texts are not produced for teaching, so the material developer needs to adjust them to be contextual and close to the real situation. 
The tasks are designed to be authentic meaning that those tasks 'replicate the communicative behaviour in the real world' (Nunan, 1988b: 4). The problem of pedagogic tasks might emerge during the sessions, for example, teachers focus on accuracy rather than the use of language. Therefore, the communicative tasks are organised in the designed materials.

Communicative is often perceived as speaking skills. As an example, some learners mentioned their needs and expectations to improve their speaking through conversation practice (Table 2). The designed materials mostly ask learners to involve in speaking practices. The issues of teaching speaking for materials developers might be difficulties in finding the best model of spoken communication and activities that focus on fluency, complexity and accuracy (Paran, 2017). According to Howard and Major (2004), materials enable learners to integrate all four language skills in an authentic manner. Hence, the designed materials attempt to comprise all four skills in communicative tasks.

Listening to a foreign language is considered the most difficult skill. The material developer and teachers have to create strategies to use spoken and written texts for listening. Ridgway (2000) finds out that listening strategies in verbal interaction are more communication than comprehension strategies. Meanwhile, reading is presented mostly as vocabulary practice and comprehension. Reading always has a purpose (Berardo, 2006). The frequent problems during the process of materials development are choosing suitable reading texts. Some challenges of the target readers are lack of vocabulary, social context influences, context effects and motivation. Consequently, the material developers have to select the reading texts carefully. 
Developing writing activities, Firkins et.al (2007) found out how to teach writing for EFL particular learners. The activity-based genre approach to teaching writing is suitable for beginners or low English proficiency. This genre-approach provides modelling, deconstructing, and understanding the language that dynamic and explicit (ibid. 2007). Writing activities cannot be separated from sentence structure, grammar and vocabulary.

As ESP emphasis on learning language skills for communication, grammar is not the focus. 'Learners' grammar needs are determined on the basis of task performance rather than through a predetermined grammar syllabus' (Richards, 2002: 153). Nevertheless, grammar will be introduced inductively- avoiding rules explanation or implicit grammar which is an integral part of the communicative task (ibid. 2002). The materials consist of grammar and target language structures that are useful and meaningful for the students in their real situations.

Overall, building vocabulary becomes a crucial part of materials development. The outcome of needs analysis shows that the learners' problem of learning English is a lack of vocabulary (Table 2). Accordingly, this material consists of learning difficult words. Difficult words might be relative to the possibility of different perceptions from materials developers and learners. Carter \& McCarty (2014) identify the difficulty of a word as a result of how it contacts with other words, how it is associated, how it is learned, its context and its pronounced ability. In ESP materials, vocabulary acquisition becomes a fundamental component because it is taken from specific texts (Wu \& Wang, 2004). In the designed materials, keywords are selected from the input text. Pictures are available to some words to ease learners. 
How are the tasks organised in the set of materials? There are different patterns of each unit meaning that there is no standard template in each lesson in the designed materials. The standard exercise sequence might help learners develop strategies and skills when they do self-learning without a teacher, time-saving and learners will be familiar, repetitive standard exercises in lessons might allow learners to get bored (McGrath, 2016), especially adult learners. According to Sifakis (2003) adults learners have unique issues of mess management, motivation and adult learning cycle, but able to combine their accumulated experiences with their autonomy and needs of learning.

Designing materials should consider how it looks attractive for both teachers and learners. Therefore, materials developers should think about the visual elements such as layout and artworks that illustrate the language context and might stimulate language practice (Hewings, 1991). Illustrations that are used in the designed materials are photographs, tables, graphics, etc. While colours and fonts type are carefully chosen to produce well-presented materials. An issue dealing with visual elements is the use of the picture for decorative purposes and basic language manipulation (Hill, 2003). The designed materials attempted to present more pictures that are meaningful with balance colours and proportional fonts and text layout.

\section{Conclusion}

In conclusion, designing teaching materials is a challenging work exploring developers' beliefs and philosophies underlying the produced materials. To design a set of materials, the writers have to consider several aspects: the context including the target learners, cultures, purposes and allocated time. In the same way, materials writers should also look upon pedagogical approaches because ESP teacher is usually as a material designer. 
Whether it is commercial or unpublished material, the writing has to base on principles and rationales as well as considering some issues.

The discussion has highlighted the needs analysis as the basis for developing teaching materials. It also examined the principles and issues of developing materials for teachers of non-English subjects in Indonesia. The designed materials should fulfil the learners' needs and expectations through a comprehensive needs analysis and syllabus design.

It is maybe useful to investigate further how the materials for other particular learners are designed especially those ESP materials which are not all published and no one-fit-all. In the same way, how to teach the designed materials need attention as well because teachers are not materials writers and vice versa. Whenever possible, teachers may evaluate the available materials before designing one to have a more improved set of materials.

\section{About the Writer}

Sri Lestari graduated from the State University of Yogyakarta with a bachelor degree in English Education. She has more than fifteen years of professional experience in teaching. She was an English teacher in several high schools in Yogyakarta. Then, she moved to West Java and managed her own language school. Being awarded a scholarship from the Indonesian government, she finally received her MA in Curriculum, Pedagogy, and Assessment from the Institute of Education, University College London, UK. She is currently a lecturer at the Faculty of Teacher Training and Education, Esa Unggul University, Jakarta. 


\section{References}

Berardo, S. A. (2006). The use of authentic materials in the teaching of reading. The reading matrix, $6(2)$.

Basturkmen, H. (2010). Developing Courses in English for Specific Purposes. New York: Palgrave Macmilan

Block, D. (1991). Some thoughts on DIY materials design. ELT journal, 45(3), 211217.

Breen, M.P. (2001). Syllabus Design. In Carter, R and Nunan, D. (ed.) The Cambridge Guide to TESOL. Cambridge: CUP. 151-159

Carter, R., \& McCarthy, M. (2014). Vocabulary and language teaching. London: Routledge.

Dearden, J. (2014). English as a medium of instruction-a growing global phenomenon. British Council. Online: http://www. britishcouncil. org/education/ihe/knowledge-centrelenglish-language-highereducation/report-english-medium-instruction (Accessed 10 April 2017).

Dudley-Evans, T. (2001). English for Specific Purposes. In Carter, R and Nunan, D. (ed.) The Cambridge Guide to TESOL. Cambridge: CUP. 131-136

Dudley-Evans, T., \& St John, M. J. (1998). Developments in English for specific purposes: A multi-disciplinary approach. Cambridge University Press.

Firkins, A., Forey, G., \& Sengupta, S. (2007). Teaching writing to low proficiency EFL students. ELT journal, 61(4), 341-352.

Flowerdew, L (2012). Needs analysis and curriculum development in ESP. In Paltridge, B., \& Starfield, S. (Eds.). The Handbook of English for specific purposes (Vol. 120). UK: John Wiley \& Sons. doi: 10.1002/9781118339855.ch17

Guariento, William, and John Morley. 'Text and task authenticity in the EFL classroom.' ELT journal 55.4 (2001): 347-353.

Hall, D. R. (2001). Materials production: Theory and practice.In A.C. Hidalg, D.Hall and J.M. jacobs (eds). Getting started: Materials writer on materials writing. Singapore: SEAMO Regional Language Center, pp. 8-14

Hewings, M. (1991). The interpretation of illustrations in ELT materials. ELT Journal, 45(3), 237-244.

Hill, D. A. (2003). The visual element in EFL coursebooks. Developing materials for language teaching, 174-182.

Howard, J., \& Major, J. (2004). Guidelines for designing effective English language teaching materials. The TESOLANZ Journal, 12, 101-109. 
Hutchinson, T., \& Waters, A. (1984). How communicative is ESP? ELT journal, 38(2), 108-113.

Hutchinson, T., \& Waters, A. (1987). English for specific purposes. Cambridge University Press.

Jolly, D. And Bolitho, R. (2011). A framework for materials writing in Tomlinson, B. (ed.) Materials Development in language teaching. 2nd ed. Cambridge: CUP. 90-115

Larsen-Freeman, D. (2000). Techniques and principles in language teaching. Oxford: Oxford University.

Lauder, A. (2008). The status and function of English in Indonesia: A review of key factors. Makara Hubs-Asia, 12(1) pp 9-20. Indonesia: FIB UI

Long, M. H. (2005). Second language needs analysis. Cambridge: Cambridge University Press.

Long, M. H., \& Crookes, G. (1992). Three approaches to task-based syllabus design. TESOL quarterly, 26(1), 27-56.

Kirkpatrick, A., 2011. English as a medium of instruction in Asian education (from primary to tertiary): Implications for local languages and local scholarship. Applied Linguistics Review, 2, pp.99-120.

McGrath, I. (2016). Materials evaluation and design for language teaching. Edinburgh University Press.

Nunan, D. (1988a). Syllabus Design. Oxford: Oxford University Press.

Nunan, D. (1988b). Principles for Designing Language Teaching Materials. Guidelines: A periodical for classroom language teachers, 10(2), 1-24.

Nunan, D. (1991). Communicative tasks and the language curriculum. TESOL Quarterly, 279-295.

Paltridge, B \& Starfield, S. (2013). The Handbook of English for Specific Purposes. Sussex: Willey-Blackwell

Paran, A. (2017). 'Session 8: Speaking and Listening'. CCMEG371B: Materials Development for Language Teaching. UCL Institute of Education. Unpublished.

Prabhu, N. S. (1984). Procedural syllabuses. Reed (ed comp.), Trends in Language Syllabus Design. Singapore University Press/RELC.

Richards, J. C. (2002). Addressing the grammar gap in task work. Methodology in language teaching: An anthology of current practice, 153-166. 
Ridgway, T. (2000). Listening strategies-I beg your pardon?. ELT journal, 54(2), 179185.

Rivers, W. M. (1987). Interactive language teaching. Cambridge University Press.

Sifakis, N. C. (2003). Applying the adult education framework to ESP curriculum development: an integrative model. English for specific purposes, 22(2), 195211.

Wang, Q., \& Castro, C. D. (2010). Classroom Interaction and Language Output. English language teaching, 3(2), 175-186.

Widodo, H. P., \& Pusporini, R. (2010). Material design: English for specific purposes (ESP). HP Widodo, \& L. Savova, The Lincom guide to materials design in ELT, 147-160.

Wu, J., \& Wang, B. (2004). The role of vocabulary in ESP teaching and learning. ELT journal, 27, 223-224. 